\title{
Teknik Reduksi PAPR pada Sistem OFDM dengan Partial Transmit Sequence (PTS) dan Selected Mapping (SLM)
}

\section{PAPR Reduction Technique on OFDM System with Partial Transmit Sequence (PTS) and Selected Mapping (SLM)}

\author{
Chaeriah Bin Ali Wael, Winy Desvasari, R. Priyo Hartono Adji \\ Pusat Penelitian Elektronika dan Telekomunikasi, Lembaga Ilmu Pengetahuan Indonesia \\ Komplek LIPI Gedung 20 Lantai 4, Jl Sangkuriang, Bandung 40135, Indonesia
}

\begin{abstract}
Abstrak
Orthogonal Frequency Division Multiplexing (OFDM) merupakan teknik modulasi multicarrier yang banyak diadopsi oleh berbagai teknologi komunikasi nirkabel untuk memenuhi kebutuhan akses broadband yang kian meningkat karena menyediakan transmisi dengan data rate tinggi. Selain itu, OFDM juga tahan terhadap efek multipath fading. Salah satu permasalahan utama pada sistem ini adalah tingginya nilai PAPR yang menyebabkan penggunaan power amplifier menjadi tidak efisien. Sebagai solusi permasalahan ini, teknik Selected Mapping (SLM) dan Partial Transmit Sequence (PTS) digunakan untuk mereduksi nilai PAPR. Kedua teknik ini dipilih karena efisien dalam mereduksi nilai PAPR. Dari hasil simulasi yang dilakukan terhadap 1000 simbol OFDM, kedua teknik ini memberikan reduksi PAPR yang semakin besar untuk jumlah subblok yang semakin banyak. Selanjutnya, kinerja kedua teknik ini dibandingkan. Dengan jumlah subblok yang sama, SLM memiliki performansi yang lebih baik dalam mereduksi PAPR dibandingkan dengan PTS.
\end{abstract}

Kata kunci: OFDM, teknik reduksi PAPR, selected mapping (SLM), partial transmit sequence (PTS), complementary cumulative distribution function (CCDF).

\section{Abstract}

Orthogonal Frequency Division Multiplexing (OFDM) is a multicarrier modulation technique that is widely adopted by a variety of wireless communication technologies to meet the needs of highly demand on broadband wireless access. It is because OFDM provides high data rate transmission and robust against multipath fading effect. One of the major drawbacks in this system is the high PAPR value which leads to inefficiency in the use of power amplifier. To solve this problem, Selected Mapping (SLM) and Partial Transmit Sequence (PTS) are used to reduce the PAPR value. Both of these techniques are efficient in PAPR reduction. From the simulation results conducted on 1000 OFDM symbol, both of these techniques provide greater PAPR reduction with increase in number of subblock. The performances of the two techniques are then compared. With the same number of subblock, SLM have a better performance in reducing PAPR compared with PTS

Keywords: OFDM, PAPR reduction technique, selected mapping (SLM), partial transmit sequence (PTS), complementary cumulative distribution function $(C C D F)$.

I.

Pada peringatan Hari Bhakti Postel ke-70, Menkominfo Rudiantara menyatakan untuk melanjutkan mewujudkan cita-cita Mahapatih Gajah Mada untuk menyatukan nusantara, khususnya dalam hal infrastruktur melalui konektivitas broadband (pita lebar) [1]. Konektivitas ini sangat penting dalam mendukung pertumbuhan ekonomi dan pemerataannya di Indonesia. Target dari Kementrian Kominfo adalah di akhir tahun 2018 semua Ibukota Kabupaten dan Kotamadya (IKK) di Indonesia telah terhubung dengan koneksi broadband. Jumlah IKK di Indonesia mencapai lebih dari 500 kota. Akses broadband dengan media wireline seperti teknologi DSL (Digital Subscriber Line) telah berkembang luas. Mengingat luasnya

\footnotetext{
* Corresponding Author.

Email: chae003@lipi.go.id

Received: July 12, 2015; Revised: November 28, 2015

Accepted: December 7, 2015

Published: December 30, 2015

(c) 2015 PPET - LIPI

doi : $10.14203 /$ jet.v15.60-65
}

wilayah Indonesia, BWA (Broadband Wireless Access) dapat menjadi alternatif karena berbagai kelebihannya dibandingkan media wireline seperti biaya implementasi dan perawatan yang jauh lebih murah serta mampu mengatasi keterbatasan jarak jangkauan teknologi DSL.

Implementasi teknologi wireless memerlukan tersedianya jalur Line of Sight (LOS) antara pengirim dan penerima. Apabila terjadi kondisi Non-Line of Sight (N-LOS) maka akan timbul redaman propagasi yang dapat menurunkan kualitas sinyal. Untuk mengurangi berbagai permasalahan pada lingkungan wireless yang N-LOS seperti multipath, delay spread yang panjang, Intersymbol interference (ISI) serta kompleksitas dalam ekualisasi adaptif, maka teknologi Orthogonal Frequency Division Multiplexing (OFDM) dapat menjadi solusi karena lebih efisien dalam mengatasi permasalahan pada lingkungan NLOS.

OFDM memiliki beberapa kelebihan dibandingkan dengan teknik akses nirkabel lainnya yang digunakan secara luas seperti TDMA, FDMA dan CDMA. Pada 
sistem OFDM, sebuah kanal radio dibagi menjadi beberapa frequency non selective subchannel/subcarrier yang lebih sempit sehingga beberapa simbol dapat ditransmisikan secara paralel namun tetap mampu memberikan efisiensi spektrum yang tinggi. Selain itu, pada setiap subcarrier dapat diterapkan teknik modulasi yang berbeda disesuaikan dengan kualitas tiap subcarrier. Implementasi sistem OFDM yang lebih fleksibel dengan kompleksitas pada transmitter dan receiver yang lebih rendah menjadikan OFDM sebagai kandidat teknologi yang banyak diadopsi untuk komunikasi yang membutuhkan laju data tinggi.

Salah satu permasalahan utama yang dihadapi sistem OFDM adalah tingginya nilai Peak to Average Power (PAPR). Sinyal OFDM terdiri dari sejumlah subcarrier yang dimodulasi secara terpisah. Jika masing-masing subcarrier memiliki fasa sinyal yang koheren, maka akan akan muncul amplitudo dengan level yang jauh lebih besar dari daya sinyalnya. Nilai PAPR yang besar akan menyebabkan sistem membutuhkan komponen RF yang memiliki daerah linear yang besar untuk mengakomodasi amplitudo sinyal yang besar tersebut. Jika hal ini tidak terpenuhi, maka akan terjadi distorsi non linear dari bentuk gelombang dan akan menyebabkan subcarrier menjadi tidak orthogonal. Sebagai akibatnya, kondisi ini akan menurunkan performansi sistem.

Penggunaan komponen RF dengan daerah linear yang besar untuk mengatasi permasalahan tingginya nilai PAPR membutuhkan biaya implementasi yang tinggi bahkan sulit untuk dilakukan. Cara lain yang dapat ditempuh adalah dengan memodifikasi sinyal untuk mengurangi nilai PAPRnya. Banyak metode telah diusulkan untuk mengurangi nilai PAPR sebagaimana dirangkum dalam berbagai literatur [2] - [5]. Secara umum, metode-metode tersebut dapat diklasifikasikan dalam 2 kategori utama, yaitu metode distorsi dan nondistorsi (distortionless/scambling). Teknik reduksi PAPR dengan metode distorsi yang paling sederhana adalah dengan melakukan clipping pada sinyal OFDM sebelum proses amplifikasi [6]. Teknik clipping sendiri dapat dikombinasikan dengan teknik lain seperti clipping berulang kemudian dilanjutkan dengan proses filtering [7]. Teknik lain yang tergolong metode distorsi adalah windowing [8], envelope scaling [9], dan teknik companding [10]. Yang termasuk metode non-distorsi antara lain Selected Mapping (SLM) [11] - [14], Partial Transmit Sequence (PTS) [13] - [16], Tone Reservation (TR) dan Tone Injection (TI) [17] serta teknik block coding [18]. Setiap teknik memiliki kelebihan dan kekurangan masing-masing sebagaimana dirangkum dalam banyak literatur [2] - [5].

Dari berbagai metode yang diusulkan, teknik SLM dan PTS mampu memberikan kinerja yang optimal dalam hal penurunan nilai PAPR. Banyak faktor turut mempengaruhi kinerja kedua teknik ini. Salah satu di antaranya adalah jumlah partisi subblok. Untuk itu, pada tulisan ini dilakukan studi pengaruh jumlah partisi sublok pada teknik SLM dan PTS terhadap reduksi nilai PAPR pada sistem OFDM. Selanjutnya dilakukan perbandingan kinerja kedua teknik dalam hal reduksi nilai PAPR.

\section{SISTEM OFDM}

OFDM adalah metode modulasi multicarrier yang merupakan kombinasi dari modulasi dan multiplexing. Pada prinsipnya, OFDM menggunakan mekanisme yang sama dengan FDM namun lebih efisien karena spasi antar kanal pada OFDM dibuat sangat dekat bahkan tumpang tindih seperti terlihat pada Gambar 1 . Walaupun saling tumpang tindih namun sebuah subcarrier OFDM tidak menyebabkan interferensi terhadap subcarrier lain yang berdekatan karena saling ortogonal. Pada FDM, mitigasi Inter-Carrier Interference (ICI) dilakukan dengan menambahkan spasi kanal antar frekuensi (disebut guard band) yang cukup lebar agar sinyal tidak saling berpotongan. Akibatnya penggunaan spektrum menjadi tidak efisien.
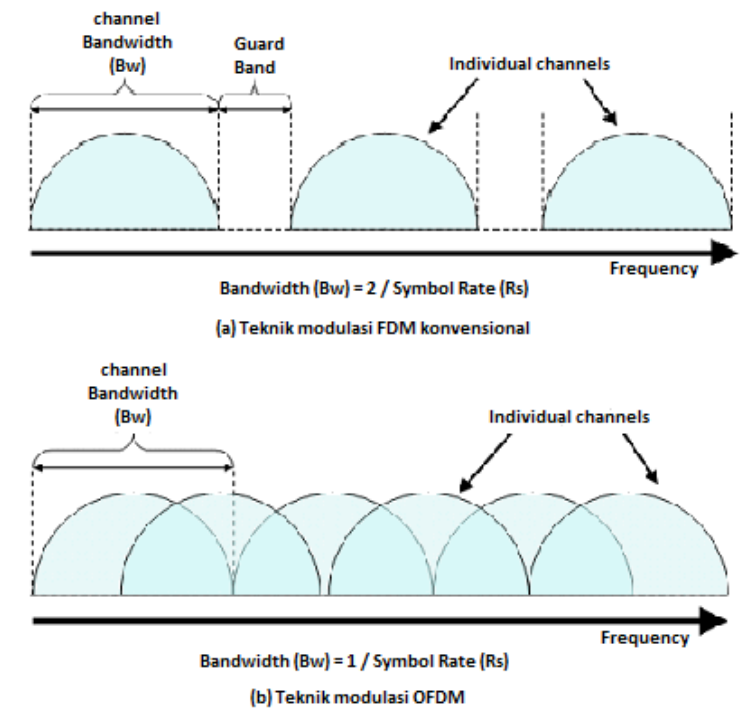

Gambar 1. Perbedaan Teknik Modulasi FDM, (a) Konvensional, dan (b) OFDM

Sistem OFDM terdiri atas blok-blok seperti yang terlihat pada Gambar 2.

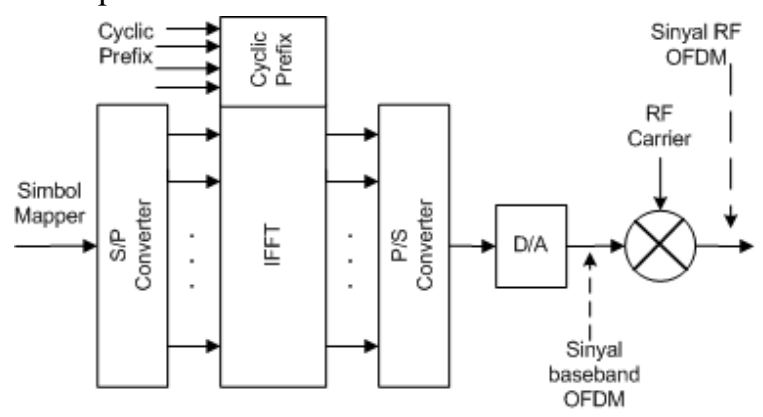

Gambar 2. Blok diagram modulasi OFDM

- $S / P$ converter

Pada sistem OFDM, setiap kanal dibagi menjadi beberapa subcarrier dengan menggunakan $S / P$ converter di mana aliran data yang masuk diubah menjadi matriks bit-bit dengan jumlah baris menyatakan jumlah subcarrier yang akan digunakan dan jumlah kolom menyatakan jumlah simbol data yang dikirimkan pada tiap subcarrier.

- Inverse Fast Fourier Transform (IFFT)

Blok IFFT berfungsi untuk membangkitkan frekuensi subcarrier yang saling ortogonal dan mengubah sinyal dari domain frekuensi ke domain waktu. 
- Penyisipan Guard Interval (GI)

Karena sistem komunikasi nirkabel rentan terhadap kanal multipath, maka dilakukan penyisipan Guard Interval untuk mencegah Intersymbol Interference (ISI) dan Inter Carrier Interference (ICI). Guard Interval yang disisipkan berupa Cyclic Prefix (CP) di mana terjadi penambahan simbol dengan cara mengcopy beberapa simbol dari akhir frame IFFT untuk dimasukkan pada awal frame. Mekanisme penyisipan CP diilustrasikan pada Gambar 3.

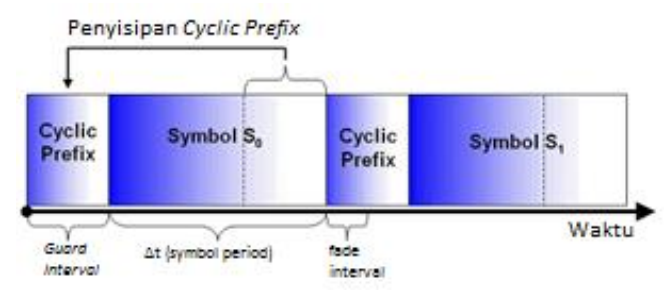

Gambar 3. Mekanisme penyisipan Cyclic Prefix (CP).

- P/S converter

Setelah menyisipkan CP, semua subcarrier harus ditransmisikan dalam sebuah sinyal. Karenanya dilakukan proses konversi aliran data dari paralel ke serial dengan menjumlahkan dan menggabungkan seluruh subcarrier menjadi sebuah sinyal OFDM.

Pada sisi penerima, dilakukan operasi yang berkebalikan dengan sisi pengirim. Sinyal yang diterima diubah dari aliran data serial ke paralel menggunakan $S / P$ converter kemudian dilakukan pelepasan cyclic prefix untuk mendapatkan kembali simbol asli. Selanjutnya dilakukan proses FFT (Fast Fourier Transform) untuk memisahkan antara frekuensi carrier dengan simbol OFDM. Keluaran blok FFT kemudian diubah dari aliran data paralel menjadi serial dengan $P / S$ converter.

\section{PAPR PADA SISTEM OFDM}

Penggunaan sejumlah subcarrier menyebabkan nilai PAPR yang tinggi pada sistem berbasis OFDM. PAPR dapat didefinisikan sebagai rasio antara daya maksimum sampel dari sinyal OFDM yang dikirimkan terhadap daya rata-rata sinyal tersebut. Bentuk diskrit dari suatu sinyal OFDM dengan $N$ subcarrier $x(n)$ dapat dinyatakan sebagai berikut:

$$
x(n)=\frac{1}{\sqrt{N}} \sum_{k=0}^{N-1} X_{k} e^{j 2 \pi \frac{k}{N} n}, \quad 0 \leq n \leq N-1
$$

di mana,

$$
\begin{array}{ll}
x(n) & \text { : sinyal OFDM diskrit } \\
X_{k} & \begin{array}{l}
\text { : input simbol yang termodulasi } \\
\text { (output mapper) }
\end{array} \\
N & \text { : jumlah subcarrier }
\end{array}
$$

PAPR sinyal OFDM diskrit diperoleh dengan menggunakan persamaan berikut:

$$
\begin{aligned}
\operatorname{PAPR}_{(\mathrm{dB})} & =10 \log _{10} \frac{P_{\text {peak }}}{P_{\text {average }}} \\
& =10 \log _{10} \frac{\max _{\mathrm{n}\left\{|x(n)|^{2}\right\}}}{\mathrm{E}\left\{|x(n)|^{2}\right\}}, \\
0 & \leq n \leq N-1
\end{aligned}
$$

di mana,

$$
\begin{array}{ll}
P_{\text {peak }} & : \text { daya puncak sinyal OFDM } \\
P_{\text {average }} & : \text { daya rata-rata sinyal OFDM } \\
E\{.\} & : \text { nilai ekspektasi } \\
N & : \text { jumlah subcarrier }
\end{array}
$$

Daya puncak sinyal yang diterima akan bernilai $\mathrm{N}$ kali daya rata-rata ketika fasa tiap subcarrier koheren. Jadi, secara teori maksimum PAPR sinyal baseband OFDM bernilai $10 \log N(\mathrm{~dB})$. Sebagai contoh, sistem OFDM dengan 128 subcarrier memiliki nilai maksimum PAPR yang mencapai 21,07 dB.

Sebagaimana telah dijelaskan sebelumnya, teknik reduksi PAPR pada sistem OFDM diklasifikasikan menjadi metode distorsi dan tanpa distorsi (scrambling). Sesuai dengan namanya, teknik reduksi PAPR yang tergolong dalam kategori distorsi memiliki kelemahan yaitu menimbulkan distorsi terhadap sinyal OFDM yang pada akhirnya akan berpengaruh ke nilai bit error rate (BER) pada sisi penerima. Walaupun demikian metode distorsi mampu memberikan reduksi PAPR yang tinggi. Karena itu dalam implementasi metode distorsi membutuhkan trade off antara kemampuan untuk mereduksi PAPR dan BER. Sementara itu kelompok metode reduksi scrambling tidak mengakibatkan distorsi terhadap sinyal OFDM. Akan tetapi kelompok ini biasanya memiliki kompleksitas komputasi yang tinggi serta membutuhkan sejumlah bit side information sehingga desain receiver pun menjadi kompleks. Pada penelitian ini digunakan metode scrambling dengan teknik Selected Mapping (SLM) dan Partial Transmit Sequence (PTS) untuk mereduksi tingginya nilai PAPR pada sistem berbasis OFDM.

\section{A. Selected Mapping (SLM)}

Ide dasar dari teknik SLM adalah membangkitkan sejumlah alternatif sinyal OFDM dari blok data asli dan selanjutnya mentransmisikan alternatif sinyal yang memiliki nilai PAPR paling minimum. Penamaan teknik ini menunjukkan bahwa satu sekuens harus dipilih dari sejumlah alternatif sekuens yang ada. SLM memanfaatkan sifat sensitif PAPR sinyal OFDM terhadap pergeseran fasa di domain frekuensi. Nilai PAPR yang tinggi direduksi dengan mengalikan alternatif sekuens sinyal OFDM dengan sekuens fasa (phase sequence). Blok diagram teknik SLM ditampilkan pada Gambar 4 dengan langkah-langkah berikut:

- Partisi keluaran mapper menjadi $N$ blok, dimana $N$ adalah jumlah subcarrier.

- Pada tiap blok, lakukan langkah-langkah berikut:

1. Kalikan tiap blok dengan sekuens fasa $\left(B_{u}\right)$ dengan nilai sekuens fasa sebagai berikut:

$$
\begin{aligned}
B_{u}(k)=e^{j \phi_{u}(k)}, \quad u & =1,2, \ldots, U \\
k & =0,1, \ldots, N-1
\end{aligned}
$$

di mana

$$
\begin{aligned}
B_{u}(k): & \text { nilai sekuens fasa blok ke- } u \text { sampel } \\
& \text { ke- } k \\
\phi_{u}(k): & \text { nilai fasa random (random phase) } \\
& \text { blok ke- } u \text { sampel ke- } k . \phi_{u} \in[0,2 \pi) .
\end{aligned}
$$

Untuk kemudahan proses semulasi, nilai $B_{u}(k) \in$ $( \pm 1)$. Alternatif sinyal OFDM dengan fasa yang telah terotasi dinyatakan sebagai berikut: 


$$
\begin{aligned}
X_{u}(k)=X(k) * B_{u}(k), \quad u & =1,2, \ldots, U \\
k & =0,1, \ldots, N-1
\end{aligned}
$$

di mana,

$$
\begin{array}{ll}
X_{u}(k): & \text { elemen sinyal OFDM yang telah } \\
& \text { terotasi } \\
* \quad: & \text { perkalian titik tiap elemen vektor }
\end{array}
$$

2. Lakukan IFFT untuk memperoleh sinyal dalam domain waktu. Secara matematis, simbol ke- $n$ dari alternatif sinyal OFDM ke- $u$ dapat dirumuskan sebagai berikut:

$$
\begin{gathered}
x_{u}(n)=\frac{1}{\sqrt{N}} \sum_{k=0}^{N-1} X_{u}(k) e^{j 2 \pi \frac{k}{N} n}, \\
0 \leq n \leq N-1
\end{gathered}
$$

3. Hitung PAPR tiap alternatif sinyal OFDM.

4. Sinyal OFDM yang ditransmisikan adalah alternatif sinyal dengan nilai PAPR minimum.

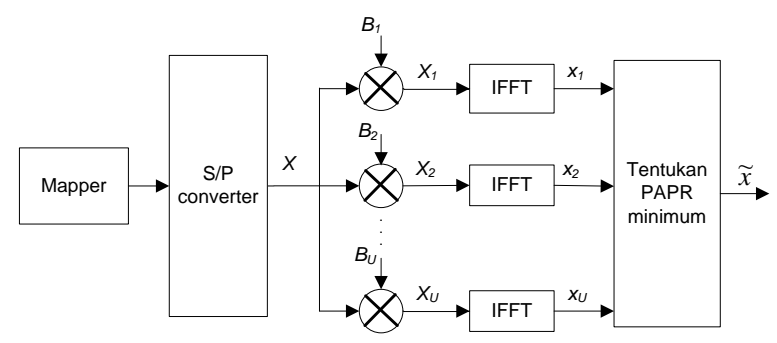

Gambar 4. Blok Diagram SLM.

Di sisi penerima, untuk memperoleh kembali simbol asli yang dikirimkan maka dilakukan proses inverse SLM. Proses ini membutuhkan informasi tentang sekuens fasa yang digunakan di sisi pengirim. Umumnya informasi tentang sekuens fasa yang dikenal sebagai side information disisipkan pada sinyal OFDM yang akan dikirim sehingga berpengaruh pada penurunan data rate simbol OFDM yang terkirim.

Berikut diberikan contoh penggunaan SLM pada sistem OFDM dengan 8 subcarrier dan jumlah sekuens fasa sebanyak 4. Blok data yang akan ditransmisikan adalah $X=(1,-1,1,1,1,-1,1,-1)^{\mathrm{T}}$. Sekuens fasa adalah sebagai berikut:

$$
\begin{aligned}
& B_{1}=(1,1,1,1,1,1,1,1)^{\mathrm{T}} \\
& B_{2}=(-1,-1,1,1,1,1,1,-1)^{\mathrm{T}} \\
& B_{3}=(-1,1,-1,1,-1,1,1,1)^{\mathrm{T}} \\
& B_{4}=(1,1,-1,1,1,-1,1,1)^{\mathrm{T}}
\end{aligned}
$$

Alternatif sinyal OFDM yang dihasilkan adalah sebagai berikut:

$$
\begin{aligned}
& X_{1}=X^{*} B_{1}=(1,-1,1,1,1,-1,1,-1)^{\mathrm{T}} \\
& X_{2}=X^{*} B_{2}=(-1,1,1,1,1,-1,1,1)^{\mathrm{T}} \\
& X_{3}=X * B_{3}=(-1,-1,-1,1,-1,-1,1,-1)^{\mathrm{T}} \\
& X_{4}=X^{*} B_{4}=(1,-1,-1,1,1,1,1,-1)^{\mathrm{T}}
\end{aligned}
$$

Selanjutnya setiap alternatif ditransformasikan ke dalam domain menggunakan IFFT dan dihitung nilai PAPR-nya. Alternatif sinyal dengan nilai PAPR minimum akan ditransmisikan sebagai sinyal OFDM.

\section{B. Partial Transmit Sequence (PTS)}

Ide dasar dari teknik PTS adalah menerapkan kombinasi pembobotan dari V subblok yang tidak saling beririsan sehingga sinyal OFDM yang ditransmisikan memiliki nilai PAPR minimum. Prinsip kerja teknik PTS dapat dilihat pada Gambar 5 dengan mengikuti langkah-langkah sebagai berikut:

1. Partisi output mapper menjadi V subblok yang tidak saling beririsan (disjoint subblock). Teknik partisi subblok PTS terdiri atas 3 cara, yaitu adjacent, interleaved dan pseudo-random. Setiap subblok memiliki ukuran yang sama.

$$
X_{v}=\left\{X_{v}^{0}, X_{v}^{1}, \ldots, X_{v}^{N-1}\right\}, \quad v=0,1, \ldots, V-1
$$

1. lakukan $N$ point IFFT terhadap setiap subblok $X_{v}$ untuk memperoleh subblok dalam domain waktu $x_{v}$.

$$
x_{v}=\operatorname{IFFT}\left\{X_{v}\right\}
$$

2. Setiap subblok dalam domain waktu $x_{v}$ selanjutnya dikali dengan faktor pembobot (weighting factor) $w_{v}$.

$$
x=\sum_{v=0}^{V-1} w_{v} x_{v}
$$

di mana,

$$
\begin{aligned}
w_{v}: & \text { faktor pembobot (weighting factor) } \\
& \text { atau faktor fasa (phase factor). } \\
& w_{v}=e^{j \phi_{v}}, \text { dengan } \phi_{v} \in[0,2 \pi) .
\end{aligned}
$$

3. Pilih kombinasi sekuens faktor fasa yang memberikan nilai PAPR minimum.

$$
\widetilde{w}_{v}=\underset{w_{v}}{\operatorname{argmin}}\left(\max _{0<n<N-1}\left|\sum_{v=0}^{V-1} w_{v} x_{v}\right|\right)
$$

di mana,

$\widetilde{w}_{v} \quad:$ sekuens faktor fasa (phase factor) optimal, $\widetilde{w}_{v}=\left\{\widetilde{w}_{0}, \widetilde{w}_{1}, \ldots, \widetilde{w}_{v-1}\right\}$.

4. Sinyal OFDM yang ditransmisikan merupakan kandidat sinyal dengan nilai PAPR minimum dan dinyatakan sebagai berikut:

$$
\tilde{x}=\sum_{v=0}^{V-1} \widetilde{w}_{v} x^{(v)}
$$

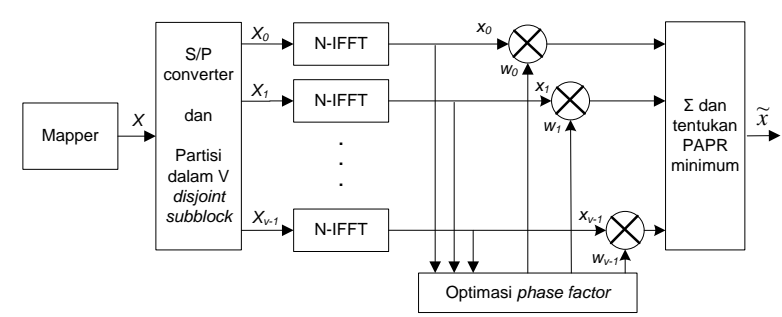

Gambar 5. Blok Diagram PTS.

Berikut contoh implementasi PTS pada sistem OFDM dengan menggunakan kasus yang sama seperti sebelumnya pada teknik SLM, yaitu sistem OFDM dengan 8 subcarrier dengan blok data yang akan ditransmisikan adalah $X=(1,-1,1,1,1,-1,1,-1)^{\mathrm{T}}$. Jumlah subblok $V=4$ dengan $W=2\left(w_{v} \in \pm 1\right)$. Teknik partisi subblok menggunakan partisi adjacent. Maka diperoleh partisi subblok sebagai berikut:

$$
\begin{array}{lllllllll}
X_{1}: & 1 & -1 & 0 & 0 & 0 & 0 & 0 & 0 \\
X_{2}: & 0 & 0 & 1 & 1 & 0 & 0 & 0 & 0 \\
X_{3}: & 0 & 0 & 0 & 0 & 1 & -1 & 0 & 0 \\
X_{4}: & 0 & 0 & 0 & 0 & 0 & 0 & 1 & -1
\end{array}
$$


Tiap subblok diterapkan IFFT dan selanjutnya dikali dengan sekuens faktor fasa. Dengan $\mathrm{W}=2$, maka terdapat kemungkinan 16 kombinasi sekuens faktor fasa. Hasil perkalian dengan nilai PAPR minimum merupakan sinyal OFDM yang dikirimkan.

\section{ANALISA KINERJA TEKNIK SLM DAN PTS}

Untuk melihat kinerja baik teknik SLM maupun PTS telah dilakukan simulasi menggunakan software Matlab. Pada kedua teknik tersebut dilakukan simulasi untuk melihat pengaruh jumlah subblok terhadap penurunan nilai PAPR. Selanjutnya dilakukan perbandingan kinerja kedua teknik dengan melihat reduksi nilai PAPR pada jumlah subblok yang sama. Adapun parameter simulasi dapat dilihat pada Tabel 1 .

TABEL 1

PARAMETER SIMULASI

\begin{tabular}{|l|l|}
\hline \multicolumn{1}{|c|}{ Parameter } & \multicolumn{1}{c|}{ Nilai } \\
\hline Jumlah simbol OFDM & 10.000 \\
\hline Jumlah Subcarrier $(\mathrm{N})$ & 128 \\
\hline Skema modulasi & QPSK \\
\hline Jumlah subblok (U/V) & 2,4 \\
\hline Faktor fasa (phase factor $=\mathrm{W})$ & \pm 1 \\
\hline Metode partisi & adjacent \\
\hline
\end{tabular}

Kinerja teknik reduksi PAPR dievaluasi menggunakan Complementary Cumulative Distribution Function (CCDF). Grafik CCDF menunjukkan seberapa sering sinyal mencapai atau bahkan melewati nilai threshold tertentu $\left(=P A P R_{0}\right)$. Kurva CCDF merupakan plot daya relatif terhadap probabilitas. CCDF dinyatakan dengan persamaan berikut:

$$
\begin{aligned}
C C D F & =P\left(P A P R>P A P R_{0}\right) \\
& =1-P\left(P A P R<P A P R_{0}\right) \\
& =1-C D F
\end{aligned}
$$

\section{A. Kinerja Teknik SLM}

Kemampuan reduksi PAPR pada SLM sangat bergantung pada jumlah subblok yang digunakan $(U)$ serta desain sekuens fasa $\left(B_{u}\right)$. Pada simulasi ini digunakan jumlah subblok $U=2$ dan 4 . Sekuens fasa yang digunakan dihasilkan dari kombinasi \pm 1 . Hasil simulasi dapat dilihat pada Gambar 6. Gambar ini menunjukkan bahwa semakin banyak jumlah subblok

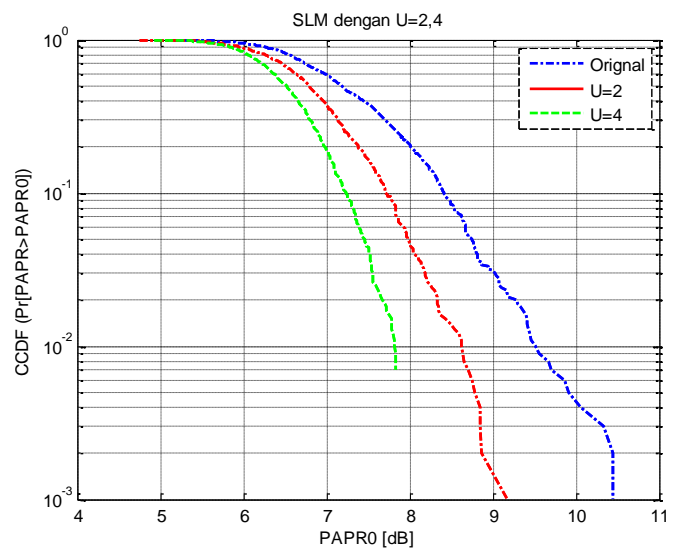

Gambar 6. Kinerja SLM dengan Jumlah Subblok yang Bervariasi. yang digunakan pada teknik SLM, maka reduksi PAPR juga semakin tinggi. Nilai CCDF $10^{-2}$ dicapai pada PAPR $=9,5 \mathrm{~dB}$ untuk sinyal original, $8,61 \mathrm{~dB}$ untuk teknik SLM dengan $\mathrm{U}=2$ dan 7,82 $\mathrm{dB}$ untuk $\mathrm{U}=4$.

\section{B. Kinerja Teknik PTS}

Seperti halnya SLM, kinerja PTS juga dipengaruhi oleh jumlah subblok yang digunakan $(V)$ serta faktor fasa $(W)$. Untuk melihat pengaruh jumlah subblok terhadap reduksi PAPR maka dilakukan simulasi dengan jumlah $\mathrm{V}=2$ dan 4 . Hasil simulasi ditunjukkan pada Gambar 7. Dari gambar ini terlihat bahwa semakin banyak jumlah subblok yang digunakan pada teknik PTS, maka reduksi PAPR juga semakin tinggi. Nilai CCDF $10^{-4}$ dicapai pada PAPR $=11,48 \mathrm{~dB}$ untuk sinyal original, 11,05 dB untuk teknik PTS dengan $\mathrm{V}=2$ dan $9,1 \mathrm{~dB}$ untuk $\mathrm{V}=4$

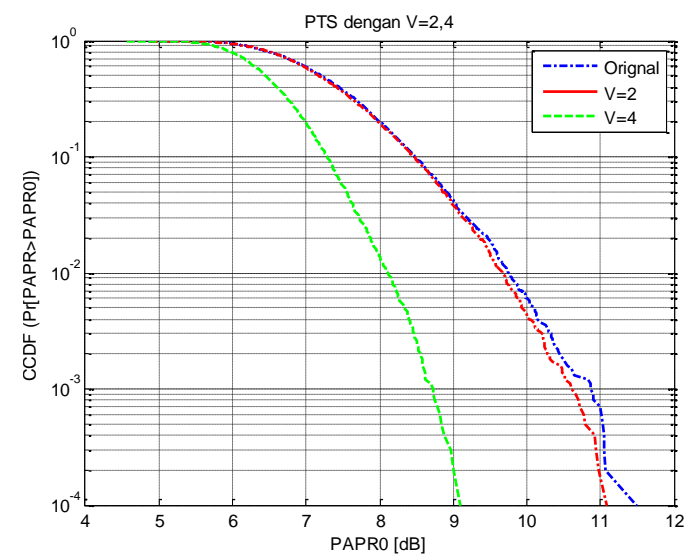

Gambar 7. Kinerja PTS dengan Jumlah Subblok yang Bervariasi

\section{Perbandingan Kinerja SLM dan PTS}

Simulasi berikut dilakukan untuk melihat perbandingan kinerja teknik SLM dan PTS. Jumlah subblok kedua teknik adalah $U=V=4$. Hasil simulasi sebagaimana terlihat pada Gambar 8 menunjukkan bahwa dengan jumlah subblok yang sama, teknik SLM memberikan performansi yang lebih baik yaitu mampu memberikan reduksi PAPR yang lebih tinggi daripada teknik PTS. Pada sinyal OFDM tanpa teknik reduksi apapun (original), CCDF $10^{-4}$ dicapai pada PAPR = $11,43 \mathrm{~dB}$. Nilai CCDF yang sama dicapai pada PAPR $=$ 9,55 dB untuk teknik reduksi PTS dan 8,26 dB untuk teknik reduksi SLM.

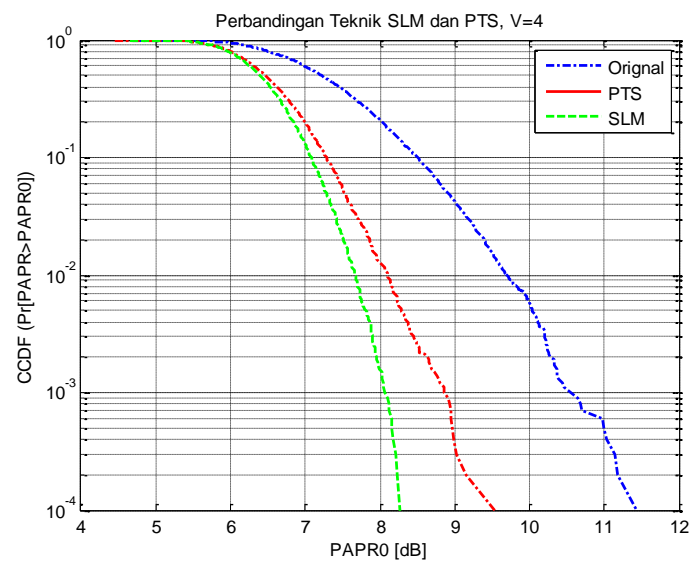

Gambar 8. Perbandingan Kinerja SLM dan PTS 
Dari hasil simulasi terlihat bahwa baik SLM maupun PTS efektif dalam mereduksi nilai PAPR pada sistem OFDM. Dari grafik pada Gambar 8 terlihat bahwa dengan teknik PTS terjadi reduksi nilai PAPR hingga mencapai $1,88 \mathrm{~dB}$ dan $3,17 \mathrm{~dB}$ untuk teknik SLM. Walaupun demikian, kedua teknik ini juga memiliki kekurangan seperti membutuhkan side information (SI) untuk mengekstrak kembali informasi sekuens faktor fasa untuk digunakan di sisi penerima serta memiliki kompleksitas komputasi yang tinggi.

\section{KESIMPULAN}

OFDM merupakan teknik modulasi yang banyak diimplementasi pada berbagai sistem komunikasi, terutama sistem komunikasi nirkabel karena memiliki banyak kelebihan. Kelemahan utama teknik modulasi ini adalah tingginya nilai PAPR. Banyak teknik untuk mengurangi nilai PAPR telah diusulkan. Setiap teknik memiliki kelebihan dan kekurangan sehingga perlu dipilih secara cermat dengan memperhatikan kondisi dari sistem pengimplementasi. Pada teknik non-distorsi, teknik SLM dan PTS populer digunakan karena efektif dalam menurunkan nilai PAPR. Dari hasil simulasi yang telah dilakukan dapat dilihat bahwa reduksi PAPR semakin besar jika jumlah subblok semakin banyak, baik untuk teknik SLM maupun PTS. Untuk jumlah subblok yang sama, teknik SLM mampu memberikan performansi yang lebih baik dalam reduksi PAPR dibandingkan dengan teknik PTS. Walaupun efektif dalam menurunkan nilai PAPR, kedua teknik ini memiliki kompleksitas komputasi yang tinggi sehingga ke depannya akan dilakukan perbaikan sehingga dapat mengurangi kompleksitas komputasi tanpa mempengaruhi kinerja keduanya dalam penurunan nilai PAPR.

\section{UCAPAN TERIMA KASIH}

Penulis mengucapkan terima kasih kepada PPETLIPI yang telah memfasilitasi terlaksananya penelitian ini.

\section{DAFTAR REFERENSI}

[1] (2015). Pemerataan akses broadband di Indonesia. [Online] Available: http://biz.kompas.com/read/2015/10/23/084024228/ Pemerataan.Akses.Broadband.di.Indonesia.

[2] S. H. Han and J .H. Lee, "An overview of peak-to-average power ratio reduction techniques for multicarrier transmission", IEEE Wireless Communications, vol. 12, no. 2, pp. 56-65, April 2005 .
[3] T. Jiang and Y. Wu, "An overview: peak-to-average power ratio reduction techniques for OFDM signals," IEEE Transactions on Broadcasting, vol 54, no. 2, pp. 257-268, June 2008.

[4] D. W. Lim, S. J. Hoe, and J. S No, "An overview of peak-toaverage power ratio reduction schemes for OFDM signals," IEEE Journal of Communications and Networks, vol. 11, no. 3, pp. 229-239, June 2009.

[5] P. Manhas and M. K. Soni, "A review of PAPR reduction techniques for OFDM system", MR International Journal of Engineering and Technology, vol. 6, no. 2, pp. 49-53, Dec. 2014.

[6] H. Ochiai and H. Imai, "performance analysis of deliberately clipped OFDM signals", IEEE Trans. on Communications, vol. 50, no. 1, pp. 89-101, Jan. 2002.

[7] S. H. Leung, S. M. Ju, G. G. Bi, "Algorithm for repeated clipping and filtering in peak-to-average power reduction for OFDM", Electronics Letters, vol. 38, no. 25, pp. 1726-1727, 2002 .

[8] R. van Nee and A. de Wild, "Reducing the peak-to-average power ratio of OFDM", in Proc. of 48th IEEE Vehicular Technology Conference (VTC 98), vol. 3, May 1998 pp. 20722076.

[9] P. Foomooljareon, W.A. Fernando, K.M. Ahmed, "PAPR reduction of OFDM systems using input sequence envelope scaling", in Proc. of The 57th IEEE Semiannual Conference on Vehicular Technology (VTC 2003-Spring), 2003, pp. 22-25.

[10] Y. Jiang, "New companding transform for PAPR reduction in OFDM", IEEE Communications Letters, vol. 14, no. 4, pp. $282-$ 284, April 2010.

[11] R. W. Baüml, R. F. H. Fisher, and J. B. Hüber, "Reducing the peak-to-average power ratio of multicarrier modulation by selective mapping", Electronics Letters, vol. 32, no. 22, pp. 2056-2057, Oct. 1996.

[12] N. V. Irukulapati, V. K. Chakka, and A. Jain, "SLM based PAPR reduction of OFDM signal using new phase sequence", Electronics Letters, vol. 45, no. 24, pp. 1231-1232, Nov. 2009.

[13] A. D. S. Jayalath and C. Tellambura, "SLM and PTS peakpower reductionof OFDM signals without side information", IEEE Trans. Wireless. Communication, vol. 4, no. 5, pp. 20062013, Sep. 2005

[14] Y. Hassan and M. El-Tarhuni, “A comparison of SLM and PTS peak-to-average power ratio reduction schemes for OFDM systems", in Proc. of IEEE 2011 4th International Conference on Modeling, Simulation and Applied Optimization (ICMSAO), April 2011, pp. 1-4.

[15] S. Muller, and J. Hubber "OFDM with reduced peak to average power ratio by optimum combination of partial transmit sequences", Elect. Lett., Communication Letters, vol. 33, no. 5, pp. 368-369, Feb. 1997.

[16] L. J. Cimini and N.R. Sollenberger, "Peak-to-average power ratio reduction of an OFDM signal using partial transmit sequences", IEEE Communications Letters, vol. 4, no. 3, pp. 8688, March 2000.

[17] J. Tellado, "Peak to average power ratio reduction for multicarrier modulation," PhD Thesis, University of Stanford, Stanford, 1999.

[18] A. Jones, T. Wilkinson, S. Barton, "Block coding scheme for reduction of peak to mean envelope power ratio of multicarrier transmission schemes", Electronics Letters, vol. 30, no. 25, pp. 2098-2099, 1994. 